\title{
Potentials of Hydrocarbon Utilization by Wood-Digesting Bacteria Isolated from the Lagos Lagoon, Nigeria
}

\author{
Olanike Maria Buraimoh *, Adewale Kayode Ogunyemi, Isaac Edward Oyegbite, Olukayode Oladipo \\ Amund, Matthew Olusoji Ilori
}

Department of Microbiology, Faculty of Science, University of Lagos, Lagos 100213, Nigeria

\author{
Article history: \\ Submission February 2019 \\ Revised February 2019 \\ Accepted December 2019 \\ *Corresponding author: \\ E-mail: \\ oburaimoh@unilag.edu.ng
}

\begin{abstract}
There is a continuous search for environmental-friendly methods to address oilpolluted environments, hence this study aimed to establish the potential of using tropical estuarine bacterial strains for degradation of crude oil in polluted environment. Microbial degradation of hydrocarbons has been considered a promising, natural, less toxic and cost-effective technology. Lignocellulose-utilizing bacterial strains (Bacillus megaterium strain NOB, Streptomyces pseudogriseolus strain EOB and Paenibacillus sp. strains ROB) were isolated from decomposing wood residues in a tropical lagoon. They were identified on the basis of morphological and biochemical characteristics, observation under scanning electron microscope and 16S rRNA gene sequencing. Microbial growth assessment coupled with biosurfactant production were performed in triplicates under aerobic batch conditions in Erlenmeyer flasks containing mineral salts medium fortified with trace elements and crude oil as the sole carbon source. The generation times of strains NOB, EOB and ROB were 28.3, 44.9 and 46.8 h respectively; with specific growth rates of $14.2,8.9$ and $8.6 \mathrm{~h}-1$, respectively on crude oil. Gas chromatographic analysis of residual hydrocarbons from the growth cultures of isolates revealed that the three strains had degraded the oil by $89.34,86.33$ and $79.37 \%$, respectively at the end of 21 days. The cell hydrophobicity of the bacterial strains also reached 83.6, 79.4 and $69.4 \%$, respectively. The results from this study suggest that wood-digesting bacterial strains from a tropical lagoon possess hydrocarbon utilization capabilities. They could therefore have potentials for deployment in the bioremediation of petrochemical spills in polluted environments.
\end{abstract}

Keywords: Bioremediation, Biosurfactant, Crude Oil, Hydrocarbons, Wooddigesting Bacteria

\section{Introduction}

The demand for petroleum and allied products has made petroleum spills inevitable in oil- producing nations, most especially in a developing country like Nigeria. Spilled petroleum hydrocarbons daily introduced into the Lagos Lagoon from industrial activities and urban waste materials constitute one of the main environmental pollutants in this ecosystem [1]. Hydrocarbon contamination is a major contribution to environmental hazards and a threat to living organisms both on land and aquatic ecosystem. Respiratory disorders in man, retardation of plants' growth and development of anoxic conditions leading to death or migration of aquatic organisms with socio-economic consequences; are some of the negative impacts of hydrocarbon pollution in the environment [2]. A major contribution to these environmental tragedies is failure to comply with stipulated environmental regulations. The Lagos Lagoon has become a victim of this environmental menace in the Southern industrial nerve-centre of Nigeria, a situation which has led to the pollution of the water body and consequently, the death or migration of estuarine aquatic life $[3,4]$. Persistence and negative impact of large-scale spills and oil pollution have also been reported in Nairobi, (Kenya) and the Niger Delta (Nigeria) by Mohammed [5] and Ite et 
al. [6] respectively. Technologies such as mechanical, burying, evaporation, dispersion, and washing are commonly used for soil remediation. However, these technologies are uneconomical and can lead to incomplete decomposition of contaminants. Bioremediation (the use of naturally occurring or deliberately introduced microorganisms to breakdown, neutralize or remove environmental pollutants, in order to clean a polluted site) is the promising environmental-friendly and relatively cost-effective technology for the treatment of contaminated sites [7]. One of the primary mechanisms by which petroleum and other hydrocarbon pollutants can be removed from the environment is through biodegradation, a process carried out by natural populations of microorganisms [8]; it appears to be more cost-effective than other remediation technologies [8]. Even though hydrocarbon degrading microorganisms are widely distributed in nature, it may be difficult to obtain isolates that possess degradative abilities for all components of petroleum. Total degradation of petroleum components often results from the activities of a consortium of microorganisms with degradative potentials for the various components of petroleum as individual organisms are capable of metabolizing a limited range of hydrocarbons [9]. Microorganisms that are capable of breaking down hydrocarbons include bacteria, yeasts, actinomycetes and filamentous fungi [10]. Bacteria are regarded as the most important in the process. Bacteria that are often isolated from hydrocarbon-polluted sites belong to the genera Pseudomonas, Sphingomonas, Acinetobacter, Alcaligenes, Micrococcus, Bacillus, Flavobacterium, Arthrobacter, Alcanivorax, Mycobacterium, Rhodococcus, and Actinobacter [11]. Organic or inorganic pollutants are naturally removed from polluted seas by marine microorganisms. This group of microorganisms are capable of adapting to harsh environmental condition in addition to their abilities to produce the required enzymes [12] and surface-active biomolecules, which enhance the dispersion of oil in water following spills in aquatic environments $[1,13]$.

Surface active biomolecules are categorized into surfactants and emulsifiers. They are both amphiphilic and are important biomolecules in various industrial processes where they are used as wetting, foaming and solubilizing agents $[14,15]$. Microbial biomolecules are produced by a wide range of microorganisms and are receiving scientific attention because of their unique characteristics which include their lower toxicity, higher biodegradability, higher foaming and compatibility and effectiveness at extreme temperature, $\mathrm{pH}$ and salinity levels compared to their chemically derived counterparts [14, 16, 17]. The ability to lower surface and interfacial tension is by adsorption of biosurfactant onto the different phases causing more interaction and mixing of different phases. In general, methods for screening and detection of biological surfactants are based on the measurement of surface and interfacial tension, drop collapse assay, oil displacement, haemolysis tests, emulsification activity and bacterial adhesion to hydrocarbon assay (BATH) also known as cell surface hydrophobicity [18]. This study was carried out using crude oil as the main carbon source as it contains numerous mixtures of varying structural complexities, mainly oxygenated and non-oxygenated hydrocarbons [19] and high molecular weight aromatics, resins and asphaltenes which are generally considered to exhibit very low rates of biodegradation and are never completely degraded [20, 21]. However, it has been reported that the inert residual mixture is an environmental contaminant with very low toxicity and bioavailability with no toxic ecological effects [10]. The work reported herein describes the abilities of wood-digesting bacterial strains isolated from a tropical estuarine ecosystem to degrade crude oil and also their potentials to produce biosurfactants for possible biotechnological applications and cleaning up of oil spills.

\section{Material and Methods \\ Isolation of microbial strains}

Lignocellulose-utilizing bacterial strains were isolated and identified as previously described [22]. They were identified on the basis of morphological and biochemical characteristics, observation under scanning electron microscope and $16 \mathrm{~S}$ rRNA gene sequencing. The bacterial isolates are S. pseudogriseolus strain EOB KF977552, B. megaterium strain NOB KF9 77554 and Paenibacillus sp. strain ROB KF977556. In previous laboratory studies, these strains have demonstrated substantial capabilities to utilize wood residues, grasses, papers and sugarcane bagasse for growth. They also showed varied abilities to utilize ligninrelated aromatic compounds [12, 23]. The isolates 
were resuscitated using Starch-Casein agar [22] and pre-enrichment was carried using Luria Bertani broth.

\section{Cultivation of isolates on hydrocarbon and bio- degradation studies}

Growth, biodegradation and biosurfactant production studies of the microbial strains were performed under aerobic batch conditions. Organisms were grown in Erlenmeyer flasks (250 mL) containing $100 \mathrm{~mL}$ of mineral salts medium (MSM). The constituents of MSM (g/L) includes: $\mathrm{NaCl}$, $0.20 ; \mathrm{MgSO}_{4} .7 \mathrm{H}_{2} 0,0.05 ; \mathrm{K}_{2} \mathrm{HPO}_{4}, 2.0 ; \mathrm{KNO}_{3}$, 2.00; $\mathrm{CaCO}_{3}, 0.02 ; \mathrm{FeSO}_{4} .7 \mathrm{H}_{2} 0,0.01 ; 1000 \mathrm{~mL}$ distilled water, $\mathrm{pH}, 7.0 \pm 0.2$ ), fortified with $1.0 \mathrm{ml}$ of sterile trace elements solution [9]. The medium was supplemented with $1.0 \%(\mathrm{v} / \mathrm{v})$ crude oil as sole carbon and energy source and was inoculated with $1.0 \mathrm{~mL}$ of inoculum after autoclaving at $121^{\circ} \mathrm{C}$. Incubation was done on a rotary shaker $\left(30^{\circ} \mathrm{C}, 150 \mathrm{rpm}\right)$ for 21 days. To monitor contamination and the effects of abiotic factors, two flasks of MSM acted as negative and positive control (the uninoculated MSM with the substrate and the inoculated MSM without any substrate). The growth experiments were set up in triplicates. The culture of each test organism $(5.0 \mathrm{~mL})$ from the sets of flasks was harvested every 3 days for determination of biomass. Growth of strains EOB and ROB was monitored by the dry weight method [24] because of their mycelial growth and pellets. Culture was filtered through a pre-weighted Whatman filter paper No 42; it was dried in an oven at $60^{\circ} \mathrm{C}$, cooled in a desiccator and weight was recorded. Drying and weighing was repeated to obtain constant weight. The weight of the empty filter paper was deducted from the final weight to obtain the weight of the strains in $\mathrm{g} / \mathrm{L}$. Increase in turbidity of the culture broth was used to monitor the growth of Bacillus strain NOB at a wavelength of $600 \mathrm{~nm}$ [25] using a spectrophotometer (Beckman coulter, DUR 800, Beckman coulter Inc. Fullerton, CA).

Generation times and the specific growth rate of the bacterial strains on hydrocarbon substrate were determined with non-linear regression of growth curves using Graph pad software, prism version 6 .

\section{Gas chromatographic (GC) analysis}

Determination of the residual hydrocarbon content in the broth during the period of incubation (21 days) was carried out using Gas chromatography [Hewlett Packard (HP) 5890 series II (California, USA) with a flame ionization detector (FID)] (Cortes et al., 2012; LAWI, 2011). Culture broth of each test organism $(10 \mathrm{~mL})$ was extracted with hexane $(10 \mathrm{~mL})$, it was then concentrated to $1.0 \mathrm{~mL}$ from which $1 \mu \mathrm{L}$ was injected into the GC column and an equivalent chromatogram was generated. Operating conditions were as follows: an $\mathrm{OV}-3$ glass column pack with internal diameter of $5.3 \mathrm{~m}$ and length of $30 \mathrm{~m}$ packed with porapak $\mathrm{N}$, $60 / 100$, a column temperature of $200^{\circ} \mathrm{C}$, an injector temperature of $60^{\circ} \mathrm{C}$, a detector temperature of $280^{\circ} \mathrm{C}, \mathrm{N}_{2}$ carrier gas and $\mathrm{H}_{2}$ at a flow rate of 22 $\mathrm{mL} / \mathrm{min}$ and temperature/ramping rate of $5^{\circ} \mathrm{C} / \mathrm{min}$. A standard profile was first obtained by injecting $1.0 \mathrm{~mL}$ of the hydrocarbon into the GC and a chromatogram was generated to serve as a calibration window with which the test sample was analysed. The peak areas of the standard and test sample chromatograms were compared and were used to calculate the concentration of the sample. Using the concept of concentration differentials between the test samples and standard, the equation below was generated:

$$
\begin{gathered}
\frac{\mathrm{C}_{1}}{\mathrm{PA}_{1}}=\frac{\mathrm{C}_{2}}{\mathrm{PA}_{2}} \\
\mathrm{C}_{1}=\frac{\mathrm{PA}_{1} \times \mathrm{C}_{2}}{\mathrm{PA}_{2}}
\end{gathered}
$$

Note:

$\mathrm{C}_{1}$ : Unknown concentration of the crude oil (test sample)

$\mathrm{PA}_{1}$ : Peak area of the crude oil (obtained from the chromatogram)

$\mathrm{C}_{2}$ : Known concentration of the standard used

$\mathrm{PA}_{2}$ : Peak area of the standard

\section{Cell surface hydrophobicity}

Cell surface hydrophobicity was measured by microbial adherence to hexadecane as described previously (25). Bacterial strains were grown in 50 $\mathrm{ml}$ basal medium containing hexadecane $(1.5 \%)$ as sole carbon source. Bacterial cells were washed twice and re-suspended in phosphate urea magnesium sulphate buffer solution ( $\mathrm{pH}$ 7.1) containing $(\mathrm{g} / \mathrm{L}) 22.2 \mathrm{~g}$ of $\mathrm{K}_{2} \mathrm{HPO}_{4} \cdot 3 \mathrm{H}_{2} \mathrm{O}, 7.26 \mathrm{~g}$ of $\mathrm{KH}_{2} \mathrm{PO}_{4}$, $1.8 \mathrm{~g}$ of urea and $0.2 \mathrm{~g} \mathrm{MgSO}_{4} \cdot 7 \mathrm{H}_{2} \mathrm{O}$ to give an optical density (OD) at $550 \mathrm{~nm}(0.5-0.6)$. The cell 
suspension $(1.2 \mathrm{~mL})$ with hexadecane $(0.2 \mathrm{~mL})$ was vortexed in a test tube vigorously for $2 \mathrm{~min}$ and left at room temperature for $1 \mathrm{~h}$. The optical density of the bottom aqueous phase was then measured at $550 \mathrm{~nm}$. Hydrophobicity was expressed as the percentage of adherence to the hydrocarbon which was calculated using the formula described previously [26].

$$
\% \text { Hydrophobicity }=100 \times \frac{1-\mathrm{A}}{B}
$$

Note:

A: OD of the aqueous phase

B: OD of the initial cell suspension

Bacterial cells grown on glucose were used as the reference of hydrophobicity.

\section{Emulsification activity}

The culture broth of each test organism was centrifuged at $10,000 \times \mathrm{g}$ for $15 \mathrm{mins}$ at room temperature. Supernatant $(5.0 \mathrm{~mL})$ was mixed with $(5.0 \mathrm{~mL})$ sterile crude oil and vortexed vigorously for 5 mins in a vortex mixer (Cole-Parmer Int., USA). It was left undisturbed for $1 \mathrm{~h}$ to separate aqueous and oil phase. Uninoculated broth was used as blank. The height of emulsion was measured and emulsification activity was recorded in terms of percentage emulsion formation [28].

$$
\text { Emulsification index }=\frac{a}{b} \times 100
$$

Note:

a: Height of emulsified layer

b: Height of the hydrocarbon phase

\section{Drop-collapse Test}

The drop-collapse test was determined as previously described [29]. The isolates were inoculated into sterile mineral salts medium with $1 \%$ crude oil and incubated for $48 \mathrm{~h}$ and then centrifuged at $3000 \times \mathrm{g}$ for $15 \mathrm{mins}$ at $25^{\circ} \mathrm{C}$ to remove the cells. Crude oil $(2 \mu \mathrm{L})$ was applied to the well regions of a cavity slide and left to equilibrate for $24 \mathrm{~h}$. Five microliters of the supernatant obtained after centrifugation was transferred to the oilcoated well regions on the cavity slide and the drop size was observed after $1 \mathrm{~min}$. This assay is dependent on the destabilization of liquid droplets by surfactants. If the liquid does not contain surfactants, the polar water molecules are repelled from the hydrophobic surface and the drops remain stable. If the liquid contains surfactants, the drops collapse (or spread). Distilled water was used in place of the culture supernatant as the negative control.

\section{Statistical analysis}

Mean generation times $\left(T_{d}\right)$ and specific growth rates $(\mu)$ of the isolates on crude oil was calculated using non-linear regression of growth curves for the period when growth rates were maximal using Prism version 5.0 (Graphpad software, San Diego, CA). Also, data generated for the growth kinetics and cell surfacehydrophobicity were expressed as mean \pm standard error using the excel software.

\section{Results and Discussion \\ Growth of isolates on hydrocarbon and biodeg- radation studies}

The bacterial strains studied utilized crude oil as substrate for growth. Generation times of strains NOB, EOB and ROB and their specific growth rates are shown in Table 1 while the timecourse growth profiles are shown in Figure 1.

\section{Gas chromatographic (GC) analysis}

GC analyses showed that $B$. megaterium utilized $89.34 \%$ of the crude oil substrate after 21 days of incubation while $S$. pseudogriseolus and Paenibacillus sp. utilized 86.33 and $79.37 \%$, of the crude oil respectively. There was a drastic re-

Table 1. Growth kinetics of Hydrocarbon-Utilizing Bacteria on Crude Oil

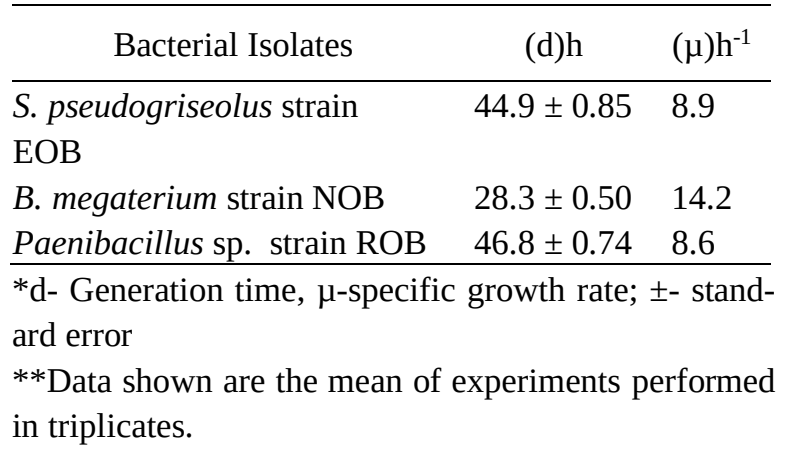

reduction in the concentration of crude oil as indicated in Table 2 and the Supplementary Figure 1. 
Table 2. Residual concentration of crude oil in the culture broths of bacterial strains

\begin{tabular}{|c|c|c|c|c|c|}
\hline \multirow{3}{*}{ Strain } & \multicolumn{5}{|c|}{ Incubation period (day) } \\
\hline & \multicolumn{4}{|c|}{ Residual concentration (mg.L ${ }^{-1}$ ) } & \multirow{2}{*}{$\% \mathrm{BD}$} \\
\hline & 0 & 4 & 14 & 21 & \\
\hline $\begin{array}{l}\text { B.megaterium strain } \\
\text { NOB }\end{array}$ & $3481.15 \pm 51.38$ & $2759.47 \pm 40.60$ & $1211.85 \pm 61.41$ & $371.04 \pm 27.35$ & $89.34 \pm 1.71$ \\
\hline $\begin{array}{l}\text { S. pseudogriseolus } \\
\text { strain EOB }\end{array}$ & $3481.15 \pm 51.38$ & $2888.80 \pm 123.77$ & $1344.07 \pm 52.20$ & $475.72 \pm 11.50$ & $86.33 \pm 3.50$ \\
\hline $\begin{array}{l}\text { Paenibacil- } \\
\text { lussp.strain ROB }\end{array}$ & $3481.15 \pm 51.38$ & $3018.99 \pm 110.54$ & $1722.95 \pm 50.17$ & $718.10 \pm 16.78$ & $79.37 \pm 1.84$ \\
\hline
\end{tabular}

\section{Biosurfactant detection}

During the growth of the organisms on crude oil, cell surface hydrophobicity increased up to 83.6, 79.4 and $69.4 \%$ for S. pseudogriseolus, B. megaterium and Paenibacillus sp. respectively. No emulsifying activity was observed and the drop-collapse assay was negative for the bacterial strains tested in this study (Table 3).

This study was carried out to determine the ability of wood-digesting $S$. pseudogriseolus, $B$. megaterium, and Paenibacillus sp to utilize hydrocarbon; as well as their biosurfactant production when grown on crude oil. The results obtained in this study showed that hydrocarbon-utilizing bacteria may not be confined to hydrocarbon polluted environments alone. Organisms which do not normally attack hydrocarbons may be able to do so after a period of adaptation [30]. Adekunle and Adebambo [31] isolated fungal strains from $\mathrm{De}$ tarium senegalense seeds which had increased growth rates in the media containing petroleum and petroleum products. Other reports also exist on the ability of microorganisms from diverse sources to utilize hydrocarbons as carbon and energy sources for growth $[1,11]$. The wood-digesting strains tested showed appreciable capability to utilize crude oil as sole carbon and energy source for growth. At the end of 21days cultivation, a biomass of 0.25 and $0.14 \mathrm{~g}$ was obtained for $S$. pseudogriselous and Paenibacillus sp while the optical density of $B$. megaterium culture increased from 0.029 to 0.785 when the absorbance was measured at a wavelength of $620 \mathrm{~nm}$. The specific growth rates were 8.9, 14.2 and $8.6 \mathrm{~h}^{-1}$ for $S$. pseudogriseolus strain EOB, B. megaterium strain NOB and Paenibacillus sp strain ROB respectively. The ability of microorganisms to utilize hy- drocarbon as a source of energy that may be used to generate cellular biomass was reported by Chikere et al. [30] and Adekunle and Adeniyi [32]. B. megaterium strain NOB displayed the lowest mean generation time of $28.3 \mathrm{~h}$ and the highest specific growth rate of $14 \mathrm{~h}^{-1}$. The cultural gas chromatographic profiles of the wood-digesting strains showed a gradual and steady reduction of crude oil by the 3 strains tested. However, the highest reduction in the concentration of crude oil (from 348 to $371 \mathrm{mg} / \mathrm{L}$ ) was obtained on day 0,4 , 14 and 21 respectively in the culture broth of $B$. megaterium strain NOB. In other words, strain NOB grew faster on crude oil; hence its higher percentage hydrocarbon biodegradation (89.34) compared to $S$. pseudogriseolus strain EOB and Paenibacillus sp strain ROB with \% BD of 86.33 and 79.37 respectively.

The percentage degradation of crude oil obtained in this study is comparable with the results of Omotayo et al. (33). In their study on the degradation of crude oil by compost microorganisms, the authors reported that Bacillus badius, Corynebacterium ulcerans and Corynebacterium amycolatum had biodegradation rates of 89.22, 88.22 and $90.82 \%$, respectively. Das et al. (34) studied the degradation of crude oil by Bacillus sp. SM-5 collected from petroleum contaminated soil. They reported a maximum degradation rate of $79 \%$ after 30 days of incubation. Also, Kawo and Bacha (35) during a crude oil degradation study using bacte rial species from soil compost reported that Bacillus sp. had a biodegradation rate of $87.5 \%$ at the end of 15 days of incubation. The report of Isikhuemhen et al. [36] on the ability of the whiterot fungus (Pleurotus tuberregium) to ameliorate crude oil polluted soil strongly support the ability 
Table 3. Cell surface hydrophobicity, emulsification activity and drop-collapse of bacterial strains

\begin{tabular}{lcccc}
\hline Bacterial Isolates & Days & CSH (\%) & $\begin{array}{l}\text { EA } \\
(\%)\end{array}$ & DC \\
\hline $\begin{array}{l}\text { S. pseudogriseo- } \\
\text { lus strain EOB }\end{array}$ & 4 & $47.8 \pm 1.23$ & 0 & 0 \\
\cline { 2 - 5 } & 14 & $55.2 \pm 0.83$ & 0 & 0 \\
\hline & 21 & $79.4 \pm 0.25$ & 0 & 0 \\
\hline $\begin{array}{l}\text { B. megaterium } \\
\text { strain NOB }\end{array}$ & 4 & $57.2 \pm 1.05$ & 0 & 0 \\
\cline { 2 - 5 } & 14 & $66.4 \pm 0.67$ & 0 & 0 \\
\hline $\begin{array}{l}\text { Paenibacillus sp. } \\
\text { strain ROB }\end{array}$ & 14 & $83.6 \pm 1.49$ & 0 & 0 \\
\cline { 2 - 5 } & 21 & $69.4 \pm 0.64$ & 0 & 0 \\
\hline
\end{tabular}

Note:

CSH-Cell surface hydrophobicity; EA- Emulsification activity; DC - Drop collapse;

* \pm - standard error.

** Data shown are the mean of experiments performed in triplicates.

of wood-digesting strains to utilize crude oil as sole carbon source. White rot fungi are well known to be one of the best studied fungi responsible for the removal of lignin components of wood and other lignocellulose compounds [37, 38]. The ability of the wood-digesting bacteria used in this study, to degrade hydrocarbons is most likely to be as a result of their inherent capability to utilize complex organic materials such as lignin and cellulose which are components of wood matter [12].

The ability of wood-digesting strains to utilize hydrocarbon is further strengthened by the proposed biogenic theory which suggested that wood matter as well as plant litter, were buried under enormous pressures and high temperatures for billions of years to form hydrocarbons [39]. This may suggest that there may be inherent similarities in the enzyme systems and genetic capacity required for degradation of lignin, a polyaromatic complex in wood and crude oil which similarly contains a variety of aromatic compounds. Hence, wood-digesting microorganisms, apart from having the genetic capacity, had the evolutionary experience to utilize crude oil, even prior to its biogenic origin in sedimentary basins. Hydrocarbon utilizing microorganisms are known to secrete extracellular enzymes and acids which are capable of breaking down the long chains of hydrogen and carbon, thereby, converting petroleum into monomers or precursors that can be absorbed for the growth and nutrition of the bacteria [10].

In an attempt to determine the ability of the bacterial strains to produce biosurfactants, cell surface hydrophobicity, drop-collapse test and emulsification activities were carried out using culture broth of the cultivated organisms on crude oil. Cell surface hydrophobicity was observed to increase gradually up to 83.6, 79.4 and $69.4 \%$ for S. pseudogriseolus, B. megaterium, and Paenibacillus sp respectively. The drop-collapse and the emulsification index were negative for all the three strains. Perfumo et al. [15] and Uzoigwe et al. [14] reported that some bacteria have developed the strategy to gain access to poorly soluble substrates by their capability to self-assembly in micelles, hemi-micelles or aggregates; whereas some interact with hydrocarbons directly by means of wallbound biosurfactants that confer the appropriate hydrophobicity on the cell surface through which contact with the substrate can take place. The substrate is then used for growth by uptake of crude oil via direct access to large oil drops by the cells, implying that biosurfactants are synthesized in a growth associated manner and that most of them remain wall-bound. The high cell hydrophobicity observed in this study may be an indication that the strains belong to the group of bacteria that synthesize cell bound biosurfactants. Cell-bound surface-active agents are important in hydrocarbon assimilation during biodegradation and bioremediation of polluted environments. When microorganisms show low surface hydrophobicity, it is an indication that emulsifying agents have been released extracellularly into the culture media [18]. In their opinion, Franzetti et al. [41] while working on the role of surface-active compounds in Gordonia, reported that microorganisms with capabilities to take up hydrocarbons by direct uptake mode, show high surface hydrophobicity; and cell bound biosurfactant production is associated with hydrocarbon uptake. Some marine microorganisms isolated by Sabnis and Juvale [29] showed negative results for drop-collapse assays and moderate $(16-45.20 \%)$ cell hydrophobicity. They concluded that some bacterial cells have high cell hydrophobicity and do not produce extracellular biosurfactants. 
Other components of the cell wall such as lipopeptides, glycolipids, mycolic and fatty acids may also contribute to the hydrophobic nature of bacterial strains [40]. The bacterial groups used in this study are generally known to possess two or more of such constituents in their cell walls. The importance of cell wall components to hydrocarbon degradation was reported by Lang and Philips [43]. In their study on the surface-active lipids in Rhodococci, they opined that hydrophobicity hampers the wetting of the cell surface which further supports the access to hydrocarbons; and that only a small portion of biosurfactants are released into the culture medium to help the preliminary emulsification. Examples of extracellular membrane vesicles that form microemulsion which plays a major role in microbial-alkane uptake include $\mathrm{M}$ protein and lipoteichoic acid in group A Streptococci, protein A in Staphylococcus aureus, prodigiosin in Serratia sp. and gramicidins in $\mathrm{Ba}$ cillus brevis. The wood digesting bacterial strains in this study probably belong to such group of microorganisms that possess extracellular membrane vesicles. In contrast to the results obtained in this study, Nadem et al. [44] optimized conditions for bioemulsifier production and reported that Streptomyces sp. SS20 produced maximum bioemulsifier activity (100\%) and bioemulsifier stability (75\%). Apart from the likely reasons explained earlier, other factors which may be responsible for these contrasting results include preliminary cell cultivation methods, source of substrate, culture condition and concentration of microelements particularly nitrogen [15]. In addition, experimental reports have shown that bioemulsifiers are often eliminated because they do not exhibit significant changes in surface/interfacial tension and may give negative results during screening tests [44]. Meanwhile, Uzoigwe et al. [14] pointed out that current research toward identification based on a broad spectrum of physical and chemical tests is insufficient to identify biosurfactants. In addition, Perfumo et al. [15] stressed the use of chromatographic assays and molecular approaches such as genomics and proteomics which in their opinion will give a clear picture of identification and distinguishing features between biosurfactants and bioemulsifiers. Although the two terms are often used interchangeably, reports have shown that differences exist in their physico-chemical properties and physiological roles although they both emulsify [14]. Bioemulsifiers are complex mixtures of hetero- and lipopolysaccharides, lipoproteins and proteins; higher in molecular weight than biosurfactants. While surfactants play the role of surface tension reduction, emulsifiers are involved in the formation and stabilization of emulsions [46, 13]. However, some biomolecules possess both surfactant and emulsifying properties which contribute to their unique functions and broad industrial uses $[14,15,18]$.

In our opinion, the outcome of this study together with accounts of the various capabilities previously reported about these strains [12, 23, 47], are strong pointers that these tropical wooddigesting bacteria of the Lagos lagoon may be promising tools to clean up hydrocarbon contamination in the environment. In addition, it is generally believed that marine organisms have developed attributes that enables them to adapt to harsh environments and are yet to be fully exploited. Hence, these tropical estuarine, wood-digesting bacteria are worthy of further pursuits for biotechnological purposes.

\section{Conclusion}

To the best of our knowledge, this is the first report on hydrocarbon degradation by wood-digesting bacteria from the Lagos lagoon. The results of this study have revealed that the wood-digesting bacterial strains of the tropical lagoon have proven to be good hydrocarbon utilizers and promising candidates for bioremediation applications and biotechnology. They can be exploited in the bioremoval of petroleum oil spills. Further work will focus on the use of chromatographic and molecular approaches for the characterization of surface-active agents from these strains during their growth on various hydrocarbons.

\section{Acknowledgment}

We appreciate the technologists at the Central Research Laboratory, University of Lagos, and those at the Department of Microbiology, University of Lagos, Akoka for their contributions.

\section{References}

1. Adebusoye SA, Ilori MO, Amund OO et al. (2007) Microbial degradation of petroleum hydrocarbons in a polluted tropical stream. World Journal of Microbiology and Biotechnology 23 (8): 1149 - 1159. doi: 10.1007/s11274-007-9345-3. 
2. Holdway DA (2002) The acute and chronic effects of wastes associated with offshore oil and gas production on temperate and tropical marine ecological processes. Marine Pollution Bulletin 44 (3): 185 - 203. doi: 10.1016/s0025-326x(01)00197-7.

3. Emmanuel BE, Chukwu LO, Azeez LO (2008) Cast net design characteristics, catch composition and selectivity in tropical open lagoon. African Journal of Biotechnology 7: 2081 - 2089.

4. Amaeze NH, Egonmwan RI, Jolaosho AF, Otitoloju AA (2012) Coastal environmental pollution and fish species diversity in Lagos Lagoon, Nigeria. International Journal of Environmental Protection 11: 8 - 16 .

5. Mohammed MA (2004) Treatment techniques of oil-contaminated soil and water aquifers, International Conference on Water Resources \& Arid Environment. pp.1-11.

6. Ite AE, Ibok UJ, Ite MU, Petters SW (2013) Petroleum exploration and production: Past and present environmental issues in the Nigeria's Niger Delta. American Journal of Environmental Protection 1 (4): 78 - 90. doi: 10.12691/env-1-4-2

7. April TM, Foght JM, Currah RS (2000) Hydrocarbon-degrading filamentous fungi isolated from flare pit soils in northern and western Canada. Canadian Journal of Microbiology 46 (1): 3849. doi: 10.1139/cjm-46-1-38.

8. Ulrici W (2000) Contaminant soil areas, different countries and contaminant monitoring of contaminants. In: Rehm HJ, Reed G eds. Environmental Process II. Soil Decontamination Biotechnology. Pp. 5 - 42. doi: 10.1002/9783527620999.ch1m.

9. Obayori OS, Ilori MO, Adebusoye SA et al. (2009) Degradation of hydrocarbons and biosurfactant production by Pseudomonas sp. strain LP1. World Journal of Microbiology and Biotechnology 25: 1615 - 1623. doi: 10.1007/s11274-009-0053-z.

10. Das N, Chandran P (2010) Microbial degradation of petroleum hydrocarbon contaminants: An overview. Biotechnology Research International: 1 - 13. doi: 10.4061/2011/941810.

11. Boudia AO (2013) Bioremediation of crude oils/complex mixture of hydrocarbons (CMH) contaminants in seawater by a halotolerant bacterial under aerobic conditions: Enterobacter cloacae, Pseudomonas spp. and Escherichia coli. Global Advanced Research Journal of Microbiology 2 (8): 131 - 136

12. Buraimoh OM, Ilori MO, Amund OO et al. (2015) Assessment of bacterial degradation of lignocellulosic residues (sawdust) in a tropical estuarine microcosm using improvised floating raft equipment. Biodegradation 104: 186 - 193 . doi: 10.1016/j.ibiod.2015.06.010.

13. Craig JP, Kieran MC, Rebecca GP (2008). Isolation of surfactant-resistant bacteria from natural, surfactant-rich marine habitats. Applied and Environmental Microbiology 74 (16): 5093 5099. doi: 10.1128/aem.02734-07

14. Uzoigwe C, Burgess JG, Ennis CJ, Rahman PK (2015) Bioemulsifiers are not biosurfactants and require different screening approaches. Frontiers in Microbiology 6: 245. doi: 10.3389/fmicb.2015.00245.
15. Perfumo A, Smyth TJP, Marchant R, Banat IM (2009) Production and roles of biosurfactant and bioemulsifiers in accessing hydrophobic substrates. In: Timnis KN eds. Microbiology of Hydrocarbons, Oils, Lipids and Derived Compounds. Berlin; Heidelberg: Springer-Verlag. Pp 1502 - 1512.

16. Ron EZ, Rosenberg E (2001). Natural roles of biosurfactants: Minireview. Environmental of Microbiology 3 (4): 229 - 236. doi: 10.1046/j.1462-2920.2001.00190.x.

17. Banat IM, Franzetti A, Gandolfi I et al. (2010) Microbial biosurfactants production, applications and future potential. Applied Microbiology and Biotechnology 87 (2): 427 - 444. doi: 10.1007/s00253-010-2589-0.

18. Satpute SK, Banpurkar AG, Dhakephalkar PK et al. (2010) Methods for investigating biosurfactants and bioemulsifiers: a review. Critical Reviews in Biotechnology 30 (2): 127 - 144. doi: 10.3109/07388550903427280.

19. Yemashova NA, Murygina VP, Zhukov DV et al. (2007) Biodeterioration of crude oil and oil derived products: A review. Reviews in Environmental Science and Bio/Technology 6: 315 - 337. doi: 10.1007/s11157-006-9118-8.

20. Tang X, Dang Z, He LY et al. (2012) Biodegradation of crude oil by an artificial microalgal-bacterial consortium. Open Access Scientific Reports: 118 - 119 .

21. Chang W, Akbari A, Snelgrove J (2013). Biodegradation of petroleum hydrocarbons in contaminated clayey soils from a subarctic site: the role of aggregate size and microstructure. Chemosphere 91: 1620 - 1626.

22. Mohseni M, Norouzi H, Hamedi J, Roohi A (2013). Screening of antibacterial producing Actinomycetes from sediments of the Caspian Sea. International Journal of Molecular and Cellular Medicine 2 (2): $64-71$.

23. Buraimoh OM, Ilori MO, Amund OO (2015) Characterization of lignocellulolytic bacterial strains associated with decomposing wood residues in the Lagos lagoon. Malaysian Journal of Microbiology 11 (3): 273 - 283. doi: 10.21161/mjm.68814.

24. Ball AS, Betts WB, Mccarthy AJ (1989) Degradation of lignin related compounds by Actinomycetes. Applied and Environmental Microbiology 55: 1642 - 1644. doi: 10.1128/aem.55.6.1642-1644.1989.

25. Chandra R, Raj A, Purohit HJ, Kapley A (2007) Characterization and optimization of three potential aerobic bacterial strains for kraft lignin degradation from pulp paper waste. Chemosphere 67 (4): 839 - 846. doi: 10.1016/j.chemosphere.2006.10.011.

26. Obuekwe CO, Al-Jadi ZK, Al-Saleh ES (2007) Sequential hydrophobic partitioning of cells of Pseudomonas aeruginosa gives rise to variants of increasing cell-surface hydrophobicity. FEMS Microbiol Letters 270: 214 - 219. doi: 10.1111/j.15746968.2007.00685.x. 
27. Ilori MO, Adebusoye SA, Ojo AC (2008) Isolation and characterization of hydrocarbon-degrading and biosurfactant producing yeast strains obtained from a polluted lagoon water. World Journal of Microbiology and Biotechnology 24 (11): 2539 2545. doi: 10.1007/s11274-008-9778-3

28. Pruthi V, Cameotra SS (1997) Production of a biosurfactant exhibiting excellent emulsification and surface active properties by Serratia marcescens. World Journal of Microbiology and Biotechnology 13: 133 - 135. doi:10.1007/bf02770821.

29. Sabnis S, Juvale V (2016). Enrichment and isolation of biosurfactant producers from marine environment International Journal of Current Microbiology and Applied Sciences 5 (4): 730 740. doi: 10.20546/ijcmas.2016.504.084.

30. Chikere CB, Okpokwasili GC, Chikere BO (2011). Monitoring of microbial hydrocarbon remediation in the soil. 3 Biotech 1: 117 - 138. doi: 10.1007/s13205-011-0014-8.

31. Adekunle AA, Adebambo OA (2007) Petroleum hydrocarbon utilization by fungi isolated from Detarium senegalense (J. F Gmelin) seeds. Journal of American Science 3 (1): 69 - 76.

32. Adekunle AA, Adeniyi AO (2015) Biodegradation of Petroleum by fungi isolated from Treculia africana (Dec'ne) seeds in Nigeria. African Journal of Environmental Science and Technology 9 (2): 126 - 135. doi: 10.5897/2015/AJEST2011.200

33. Omotayo AE, Ojo OY, Amund OO (2012) Crude oil degradation by microorganisms in soil composts. Research Journal of Microbiology 7 (4): 209 - 218. doi: 10.3923/jm.2012.209.218

34. Das MP (2015) Microbial degradation of crude oil by Bacillus sp.: A bioremedial approach. International Journal of ChemTech Research 8 (8): 245 - 249.

35. Kawo AH, Bacha HY (2016) Crude oil degradation by Bacillus and Micrococcus species isolated from soil compost in Kano, Nigeria. Bayero Journal of Pure and Applied Sciences 9 (1): 108 - 117. doi: 10.4314/bajopas.v9i1.17.

36. Isikhuemhen O, Anoliefo G, Oghale OI (2003). Bioremediation of crude oil polluted soil by the white rot fungus, Pleurotus tuberregium (Fr.) Sing. Environmental Science and Pollution Research 10 (2): 108 - 112. doi: 10.1065/espr2002.04.114.
37. Higuchi T (2002) Biochemistry of wood components: Biosynthesis and microbial degradation of lignins. Wood Research 89: $43-51$.

38. Dashtban M, Schraft H, Syed TA, Qin W (2010) Review article fungal biodegradation and enzymatic modification of lignin. International Journal of Biochemistry and Molecular Biology 1 (1): $36-50$

39. Ringle K (1999) A Scientific Heretic Delves Beneath the Surface, The Washington Post. Retrieved June 23, 2009. doi: 10.3886/icpsr27765.v2.

40. Perfumo A, Smyth TJP, Marchant R, Banat IM (2010) Production and roles of biosurfactants and bioemulsifiers in accessing hydrophobic substrates. Handbook Hydrocarbarbon Lipid Microbiol. pp. 1501 - 1512. doi: 10.1007/978-3-540-775874_103.

41. Franzetti A, Bestetti G, Caredda P et al. (2008) Surface-active compounds and their role in the access to hydrocarbons in Gordonia strains. FEMS Microbiology Ecology 63: 238 - 248. doi: 10.1111/j.1574-6941.2007.00406.x

42. Lang S, Philp JC (1998) Surface-active lipids in rhodococci. Antonie Van Leeuwenhoek 74: 59-70.

43. Nadem HH, Sura A, Hutaf A (2014) Optimized conditions for bioemulsifier production by Local Streptomyces sp. SS 20 isolated from hydrocarbon contaminated soil. Romanian Biotechnology Letters 19 (1): 15.

44. Ellaiah P, Prabhakar T, Sreekanth M (2002) Production of glycolipids containing biosurfactant by Pseudomonas species. Indian Journal of Experimental Biology 40: 1083 - 1086.

45. Pieper DH, Reineke W (2000) Engineering bacteria for bioremediation. Curr. Opinion. Biotechnology 11: 262 - 270. doi: 10.1016/s0958-1669(00)00094-x.

46. Buraimoh OM, Amund OO, Ilori MO (2015) Kraft lignin degradation by autochtonous Streptomyces strains isolated from a tropical lagoon ecosystem. Journal of Microbiology, Biotechnology and Food Sciences 5 (3): 248 - 253. doi: 10.15414/jmbfs.2015/16.5.3. 


\section{Supplementary 1}

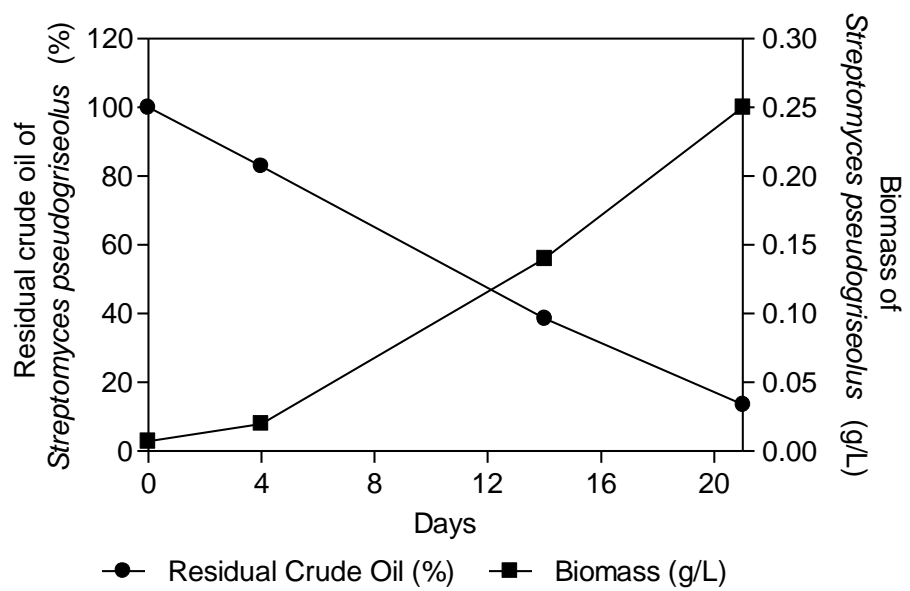

(a)

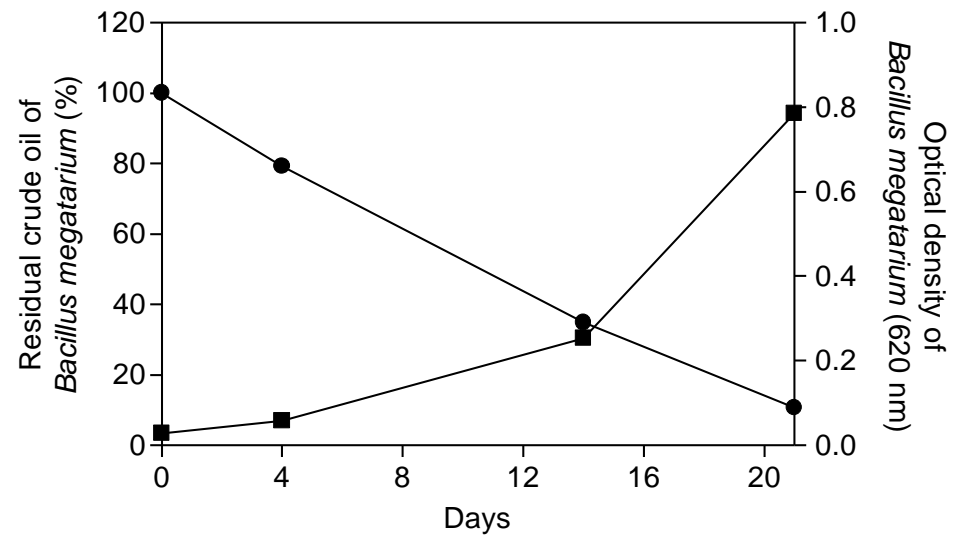

$\rightarrow \%$ Residual Crude Oil $\quad \rightarrow$ Optical Density $(\mathrm{nm})$

(b)

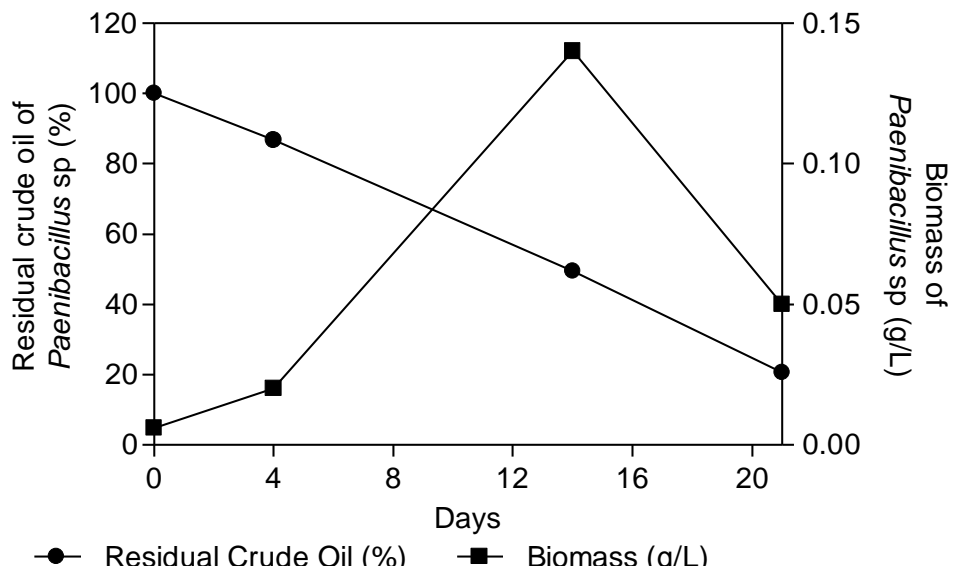

(c)

Figure 1. Growth profiles and crude oil degradation by pure cultures of $S$. pseudogriseolus (a), $B$. megaterium (b), and Paenibacillus sp. 